\title{
Effect of iron fortified ready to drink beverage in combating anemia
}

\author{
Amal Shaukat ${ }^{1}$, Muhammad Nadeem ${ }^{1 *}$, Arshad Mahmood ${ }^{2,3}$, Zafar \\ Iqbal Khan ${ }^{4}$, Mian Anjum Murtaza ${ }^{1}$, Ahmad Din $^{5}$, Mian Nadeem Riaz \\ Lala Rukh ${ }^{1}$, Hira Fatima ${ }^{4,7}$ and Ghulam Mueen-ud-Din ${ }^{1}$ \\ 1. Institute of Food Science and Nutrition, University of Sargodha, Sargodha-Pakistan \\ 2. Beijing Advance Innovation Center for Food Nutrition and Human Health, Beijing Technology and Business \\ University, Beijing-China \\ 3. Beijing Engineering and Technology Research Center of Food Additives, School of Food Science and Chemical \\ Engineering, Beijing Technology and Business University, Beijing-China \\ 4. Department of Botany, University of Sargodha, Sargodha-Pakistan \\ 5. National Institute of Food Science \& Technology, University of Agriculture, Faisalabad-Pakistan \\ 6. Process Engineering R\&D Center, Taxes A\&M University, College Station, Texas-USA \\ 7. Department of Botany, University of Lahore, Sargodha Campus-Pakistan \\ *Corresponding author's email: mnadeemft@gamil.com \\ Citation \\ Amal Shaukat, Muhammad Nadeem, Arshad Mahmood, Zafar Iqbal Khan, Mian Anjum Murtaza, Ahmad Din, Lala \\ Rukh, Mian Nadeem Riaz, Hira Fatima and Ghulam Mueen-ud-Din. Effect of iron fortified ready to drink beverage \\ in combating anemia. Pure and Applied Biology. Vol. 9, Issue 1, pp798-808. \\ http://dx.doi.org/10.19045/bspab.2020.90086
}

Received: 30/08/2019 Revised: 25/11/2019

Accepted: 26/12/2019

Online First: 30/12/2019

\section{Abstract}

Food based approach has emerged as a suitable technology to combat micronutrient disorders. Food fortification with iron is the best strategy to combat iron deficiency anemia (IDA). The effect of an iron fortification can be judged through efficacy studies with improvement in the iron status of the target subjects. The purpose of conducting this study was to find out the effect of $\mathrm{FeSO}_{4} \cdot 7 \mathrm{H}_{2} \mathrm{O}$ in combating IDA among the female students of BS $6^{\text {th }}$ Semester at Institute of Food Science and Nutrition, University of Sargodha, Sargodha. A preliminary demographic survey of 100 students was conducted and Hb level of 50 students were checked at University Medical and Diagnostic Center, UOS, Sargodha. Forty volunteer students $(19-22 \mathrm{Y})$, who were anemic $(\mathrm{Hb}<12 \mathrm{~g} / \mathrm{dL})$ were enrolled for the efficacy study. One group (A) received ready to drink beverage without fortification, while the other group (B) received fortified drink containing $40 \mathrm{ppm} \mathrm{FeSO}_{4} \cdot 7 \mathrm{H}_{2} \mathrm{O}$ for a period of 3 months. The overall increase in $\mathrm{Hb}$ level was from 9.85 to $9.98 \mathrm{~g} / \mathrm{dL}$ in group (A) while it was 10.53 to $11.52 \mathrm{~g} / \mathrm{dL}$ in group (B) after 3 months. In case of storage and treatments, the observed difference was significant $(\mathrm{p}>0.05)$ and highly significant $(p \leq 0.01)$ respectively. It is concluded that ready to drink beverage is good vehicle for iron fortification and also a source of utilization of seasonal fruits and vegetables.

Keywords: Anemia; Efficacy; Fortification; Iron; RTD

Introduction

The deficiency of Iron is the main cause of anemia [1] and it is caused due to insufficient iron required in normal red blood cells formation and it typically results by severe blood loss, reduced intake of iron, or both. Production of diminished red blood cells occurs in the body due to low iron stores which cause iron deficiency anemia $[2,3]$. Anemic patients might suffer with light headedness, dyspnea and weakness; though, mild anemia may possibly produce 
slight in the way of clinical signs and symptoms [4].

The anemia caused by deficiency of Iron in all age groups, is a main nutritional problem in Pakistan [5]. In reproductive age women, the anemia caused by deficiency of iron occurs up to $50 \%$ [6]. As a result, the rate of maternal mortality is high and in Pakistan. The major causes are found to be nutritional, i.e. Iron's dietary intake is not sufficient to fulfill the body's physiological needs. The other responsible factors are that iron bioavailability from cereal based foods is low, dietary practices are poor and people's purchasing power is low [5]. The single cost effective approach is food fortification using iron that can provide enduring improvement of iron [7]. Human diet must consist of variety of fruits. It has been usually reported that the possibility of chronic disease like cancer and cardiovascular disease can be decreased by consumption of diets loaded with fruit and vegetables [8, 9]. Peaches as an economic crop are therefore recommended for their numerous health benefits [10]. Many medicinal benefits are associated with peach because of the presence of important bioactive compounds [11]. In human nutrition, apricot has an important place and can be consumed fresh, dried or processed fruit. The high mineral contents of the apricot fruit make them helpful for treatment of bronchitis, blood poisoning, anemia, tuberculosis and asthma. The apricots are rich in iron content which make them useful in the fight against anemia and also consist of small amounts of copper, helps in absorption of iron in body. These fruits are antiseptic, emetic, ophthalmic and antipyretic [12]. The beetroot provides iron and vitamin $\mathrm{C}$ in addition to major nutrients including potassium and folate. Large quantity of biologically available antioxidants are present in beetroot juice [13] in addition to numerous health beneficial compounds like soluble fiber, niacin, sodium, phosphorus, zinc, calcium, iron, folic acid and magnesium. In the juice of beetroot, the particular concern arises for the reason that high amount of polyphenol compounds are present in it [14]. To overcome the situation of anemia caused by deficiency of iron in Pakistan, fruit and vegetables based beverage of nutritional qualities was prepared. The objective of this project was to utilize seasonal fruits and vegetables for the development of ready to drink beverage fortified with iron to combat anemia through human subject.

\section{Materials and methods}

From the local bazar of Sargodha city, fully ripe seasonal fruits were purchased \& the other materials and chemicals were purchased from the chemical store, Faisalabad. To remove dust and dirt, the fruits were washed and sorted properly. Fruit pulp was made after trimming and peeling of fruits. The juice extractor was used to extract juice. Pre-weighed ingredients were blended and chemicals were added for preparing drink. Two different formulations were prepared To (natural drink without fortificant) and $\mathrm{T}_{1}$ (natural drink with fortificant) (Table 1).

\section{Physico-chemical analysis of drink}

The methods of AOAC [15] were used to find out total soluble solids. By the method No. 942.15 of AOAC [15], the juice acidity was determined. $\mathrm{pH}$ of the juices was measured by the method No. 981.12 as described in AOAC [15]. Non-reducing sugars, reducing sugars and total sugars and were measured by Lane and Enyon method in AOAC [15]. The concentration of sugar ( ${ }^{\circ}$ Brix) was divided by the concentration of citric acid to get the sugar/acid ratio of the drinks [16]. Method No. 42-11 of AACC [17] was used to determine total plate count. Method No. 42-50 of AACC [17] was used to find out mold/yeast count. The preparation of iron analysis sample was done by following the procedure of Duhan et al. [18]. The atomic absorption spectrophotometer (Model: Varian AA-240) was used to run the filtered sample solution. The iron sample 
contents were measured by the respective standard curve prepared for each element [17].

Table 1. Formulation of fruit and vegetables based beverage

\begin{tabular}{|c|c|c|}
\hline Ingredients & Quantity $\mathbf{T}_{0}$ & Quantity $\mathbf{T}_{1}$ \\
\hline Apricot $(\mathrm{g})$ & 100 & 100 \\
\hline Peach $(\mathrm{g})$ & 80 & 80 \\
\hline Sugar $(\mathrm{g})$ & 100 & 100 \\
\hline Beetroot juice $(\mathrm{ml})$ & 20 & 20 \\
\hline Water $(\mathrm{ml})$ & 800 & 800 \\
\hline $\mathrm{CMC}(\mathrm{g})$ & 1 & 1 \\
\hline Citric acid $(\mathrm{g})$ & 1 & 1 \\
\hline Sodium benzoate $(\mathrm{g})$ & 1 & 1 \\
\hline Ferrous sulphate $\mathrm{FeSO}_{4} .7 \mathrm{H}_{2} \mathrm{O}(\mathrm{g})$ & - & 0.1628 \\
\hline
\end{tabular}

\section{Efficacy study}

This randomized clinical trial was done at the Institute of Food Science and Nutrition, University of Sargodha, Sargodha. Female students of 20-22 years of age were selected for this study. The protocol was reviewed and its approval was done by the Ethical Committee from the National Institute of Food Science \& Nutrition, University of Sargodha. The students were randomly assigned to consume $200 \mathrm{~mL} /$ day of freshly prepared drink either fortified with $0.162 \mathrm{~g} / \mathrm{L}$ of ferrous sulphate.

Every student went through a thorough examination of blood like liver function test (LFT), renal function test (RFT), hemoglobin test and complete blood count (CBC). They also went through physical examination which includes body mass index (BMI), weight, height, pulse rate, blood pressure and body fat composition analysis using the Tanita TBF-410 Body Composition Analyzer (Tanita Corp., Tokyo, Japan).

Twenty healthy subjects (female) and twenty subjects with anemia (female) were enrolled for the study. Students were instructed to avoid unnecessary vigorous activities and to take normal diet. Blood samples were obtained from all subjects for liver function test (LFT), renal function test (RFT), hemoglobin test and blood count
(CBC). These tests were performed during the beginning and at the end of study period of three months.

\section{Statistical analysis}

The obtained data for different parameters was statistically analyzed for finding the significance level among quality parameters of various ready to serve drinks with the help of CRD (complete randomized design) and two factor factorial design and means were compared [19]. The significance level was set to be at $\mathrm{p} \leq 0.05$.

\section{Results and discussion}

Ready to drink beverage was prepared by utilizing seasonal fruits and vegetables like apricot, peach and sugar beet. Fruit pulp and beet juice was blended and fortified with ferrous sulphate. Physico-chemical and microbiological analysis of the drinks was done. The analysis of drinks was also done for their sensory characteristics to assess their suitability by an untrained panel of judges. Clinical nutritional study also carried out on human subjects for three months. The results are explained and discussed below.

\section{Physico-chemical analysis}

\section{Titratable acidity}

The mean values of acidity were $0.39 \pm 0.03 \%$ and $0.43 \pm 0.03 \%$ for $\mathrm{T}_{0}$ and $\mathrm{T}_{1}$ respectively. The range of mean values for treatments was from $0.39 \pm 0.03$ to $0.43 \pm 0.03 \%$ having high acidity in case of 
$\mathrm{T}_{1}(0.46 \%)$ and low in $\mathrm{T}_{0}(0.39 \%)$. The change in acidity might be due to the addition of ferrous sulphate $\left(\mathrm{FeSO}_{4} \cdot 7 \mathrm{H}_{2} \mathrm{O}\right)$. The increasing acidity might be because of the reason that the amount of weekly ionized acids and acid's salts increases in their storage duration. The acid formulation occurs by the oxidation of reducing sugars, breakdown of pectin substances and degradation of polysaccharides which causes the acidity to rise (Figure 1).

Total soluble solids and $\mathrm{pH}$

The mean values of TSS were $12.09 \pm 0.08$ and $12.14 \pm 0.04$ for $T_{0}$ and $T_{1}$ respectively.
The $\mathrm{pH}$ mean values for ready to serve drinks are presented in the (Figure $2 \& 3$ ). The mean values for $\mathrm{pH}$ were $4.16 \pm 0.09$ and $3.91 \pm 0.09$ for $T_{0}$ and $T_{1}$ respectively. For treatments, the mean values ranged from $4.16 \pm 0.09$ and $3.91 \pm 0.09$ having high $\mathrm{pH}$ in case of $T_{0}$ (4.16) and low in $T_{1}$ (3.91). The reason of change in $\mathrm{pH}$ of ready to drink beverage might be the change in acidity level of fruits and addition of citric acid and ferrous sulphate. The increase in acidity may be the cause of decrease in $\mathrm{pH}$ because $\mathrm{pH}$ and acidity are inversely related with each other.

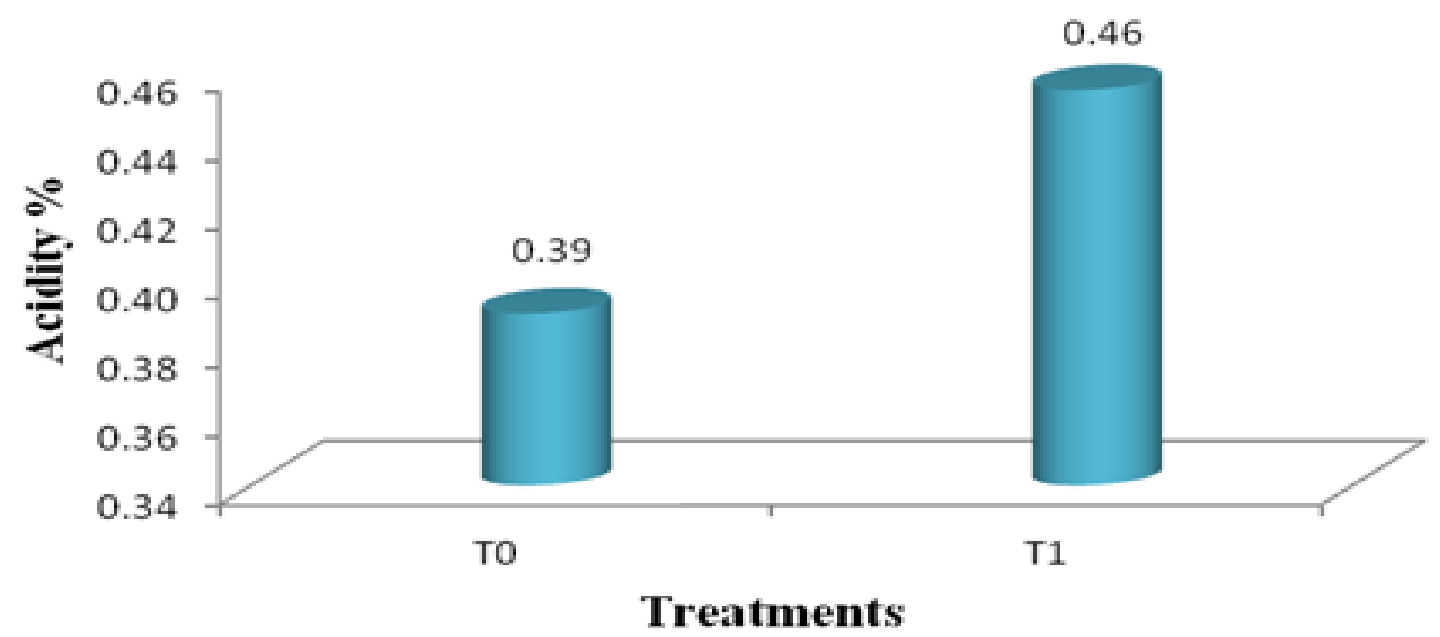

Figure 1. Mean values of titrate able acidity in ready to drink beverage

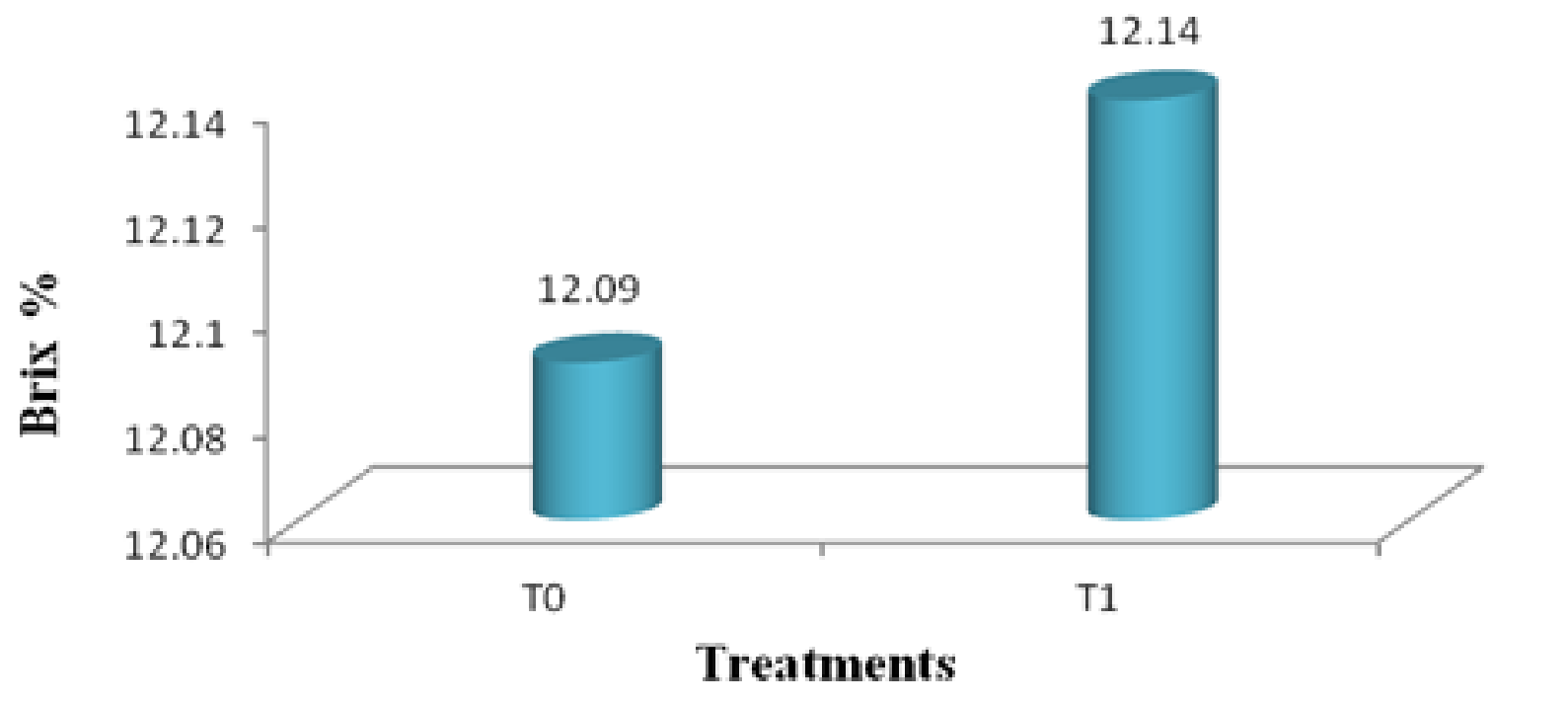

Figure 2. Mean values of TSS in ready to drink beverage 


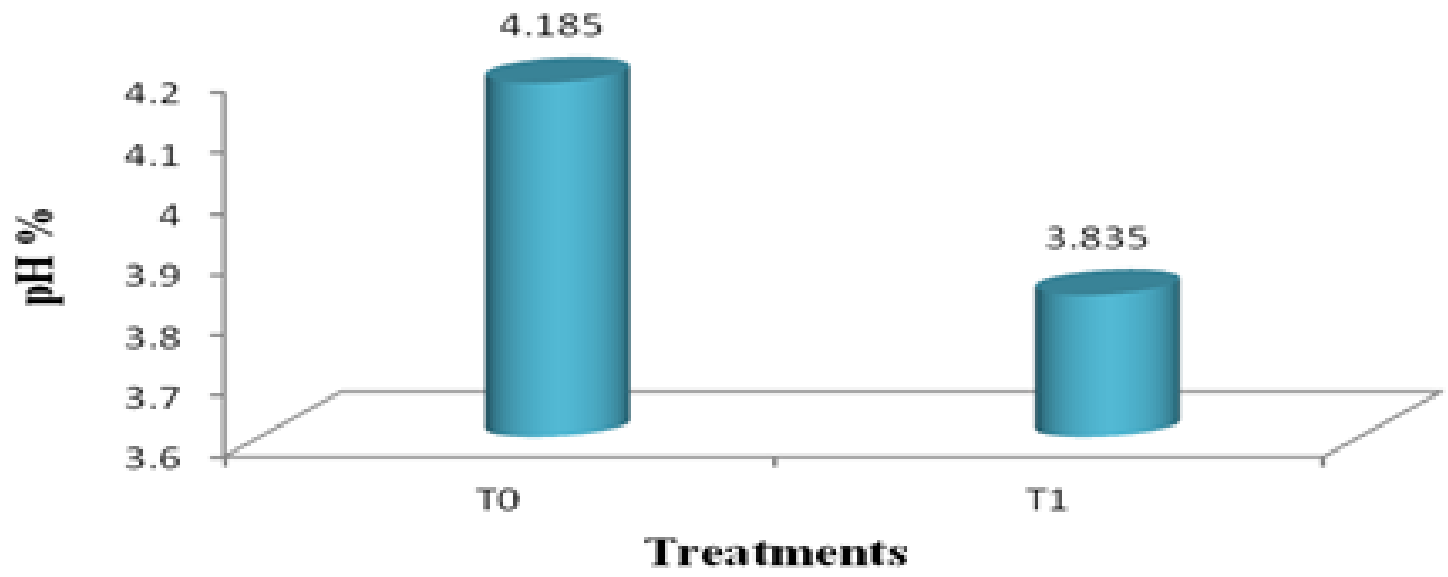

Figure 3. Mean values of $\mathrm{pH}$ in ready to drink beverage

\section{Determination of sugars}

The mean values for reducing sugars were $1.56 \pm 0.09\left(\mathrm{~T}_{0}\right)$ and $1.6 \pm 0.07 \%\left(\mathrm{~T}_{1}\right)$, nonreducing sugars were $10.36 \pm 0.31\left(\mathrm{~T}_{0}\right)$ and $10.35 \pm 0.19 \%\left(\mathrm{~T}_{1}\right)$ and total sugars were $11.92 \pm 0.27\left(\mathrm{~T}_{0}\right)$ and $11.95 \pm 0.19 \%\left(\mathrm{~T}_{1}\right)$ in RTS drink (Figure 4-6). The results are similar to the findings of Bajwa et al. [26]. The similar results were also observed by Nilugin and Mahendran [27] in a study related to preparation of RTS beverage from palmyrah pulp.

\section{Sugar/Acid Ratio}

It was measured by divided the concentration of sugar $\left({ }^{\circ}\right.$ Brix $)$ with the concentration of citric acid (acid value) to find the drink's sugar/acid ratio. The analysis of variance indicated that treatment differ significantly for their sugar acid ratio $(p \leq 0.05-0.01)$. The mean values for sugar/acid ratio were $31.15 \pm 2.57$ and $26.75 \pm 1.53$ for $T_{0}$ and $T_{1}$ respectively. The mean values for treatments ranged from $31.15 \pm 2.57$ to $26.75 \pm 1.53$ (Figure 7). The sugar/acid ratio was greater in case of $\mathrm{T}_{0}$ $(31.15 \pm 2.57)$ as compared to $\mathrm{T}_{1}$ $(26.75 \pm 1.53)$.

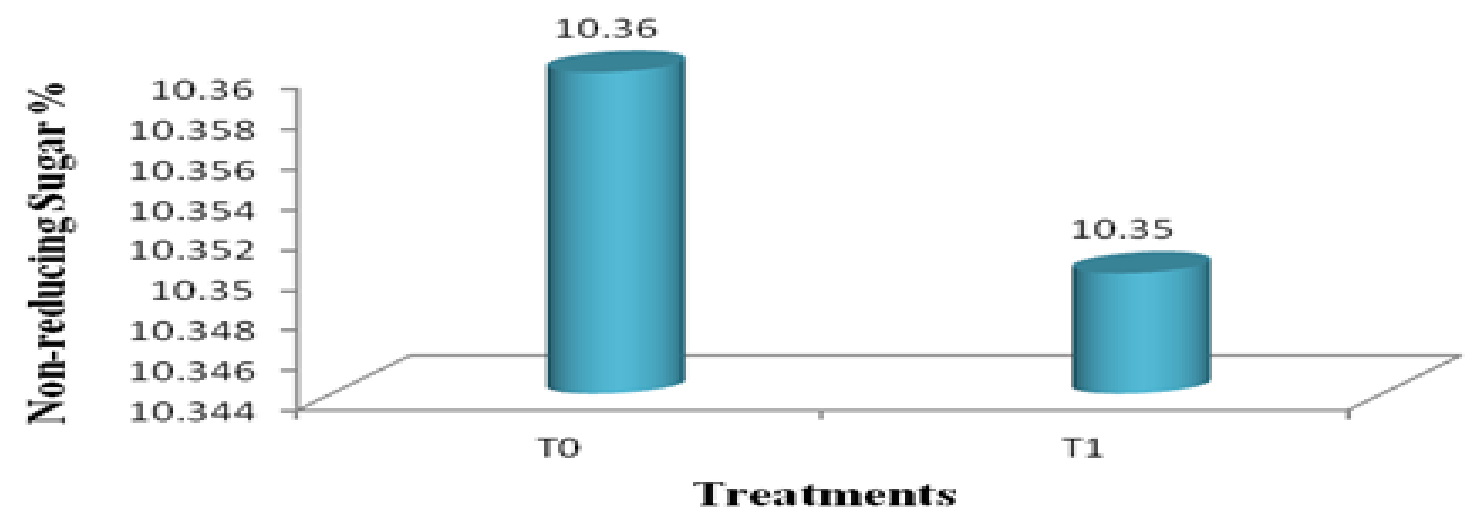

Figure 4. Mean values for reducing sugar content (\%) in ready to drink beverage 


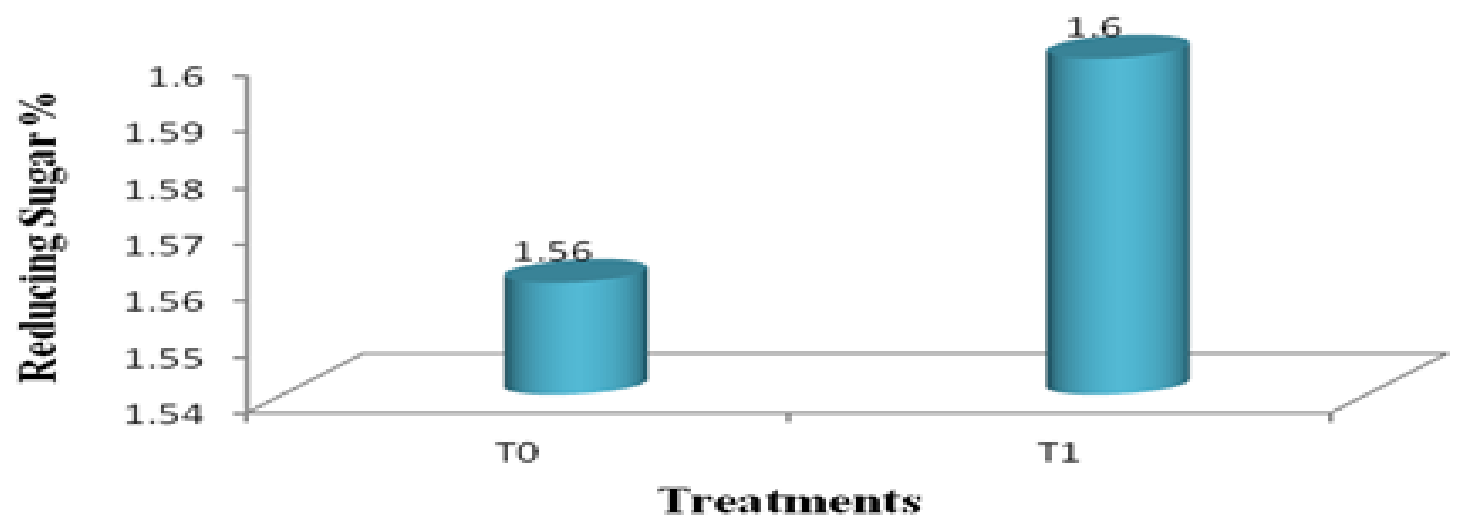

Figure 5. Mean values for non-reducing sugar content (\%) in ready to drink beverage

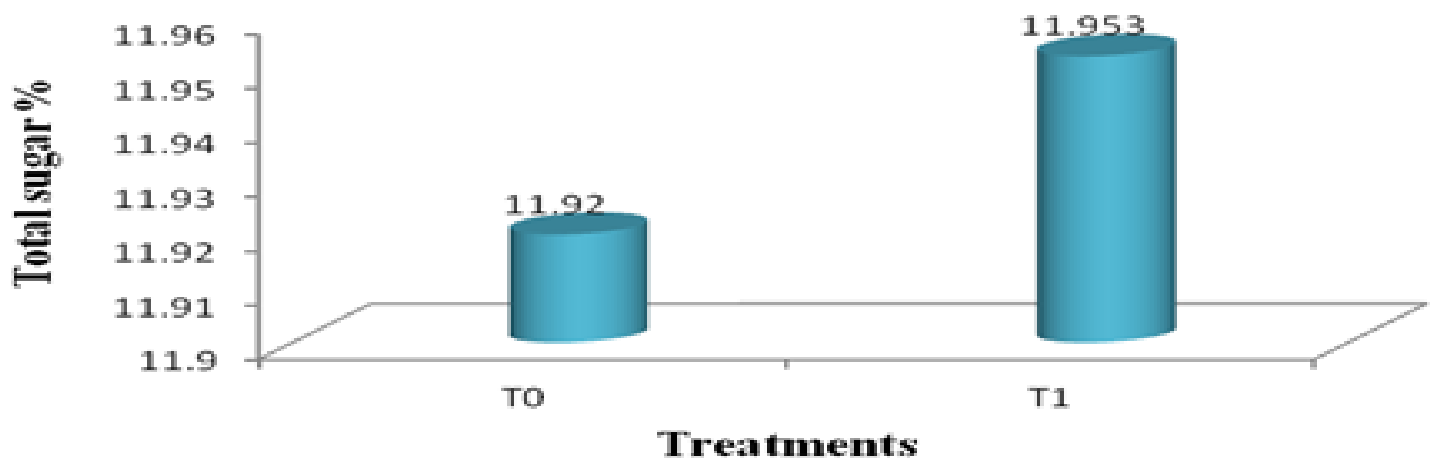

Figure 6. Mean values of total sugar content (\%) in ready to drink beverage

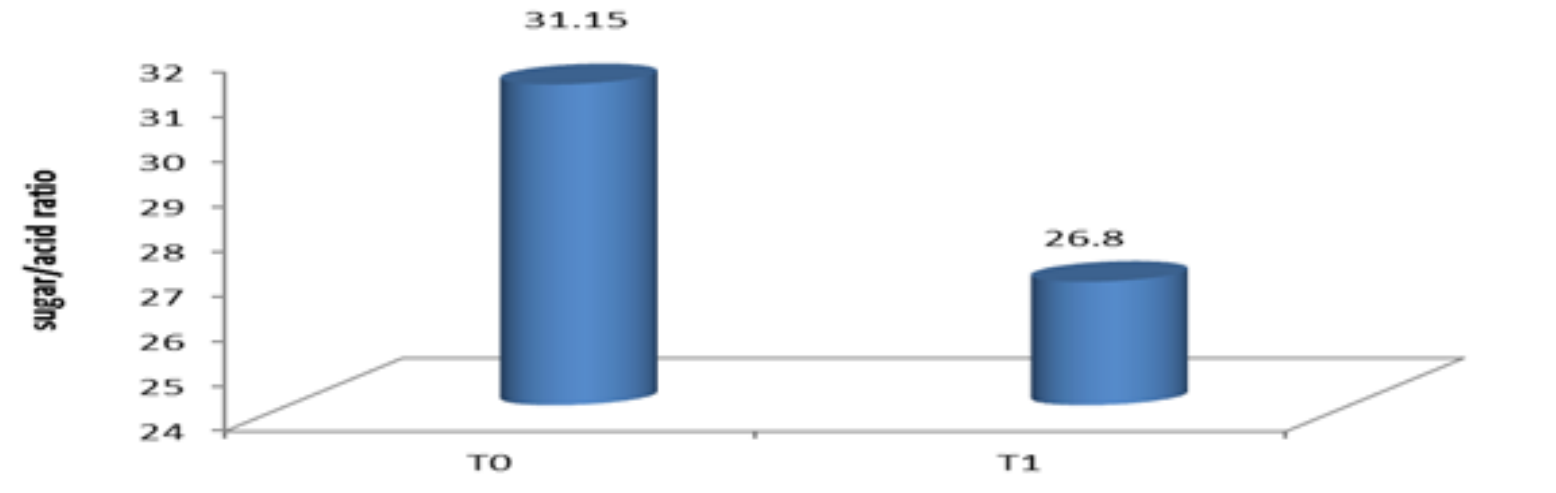

Figure 7. Mean value for sugar/acid ratio in ready to drink beverage

Iron content

The mean values for iron content were $7.15 \pm 0.26(\mathrm{ppm})$ and $40 \pm 1.26(\mathrm{ppm})$ for $\mathrm{T}_{0}$ and $\mathrm{T}_{1}$ respectively (Figure 8 ). The mean values for treatments ranged from $7.15 \pm 0.26$

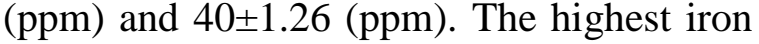
concentration was found in case of $\mathrm{T}_{1}(40$ $\mathrm{ppm})$ while the minimum iron content was found in $\mathrm{T}_{0}(7.15 \mathrm{ppm})$. 


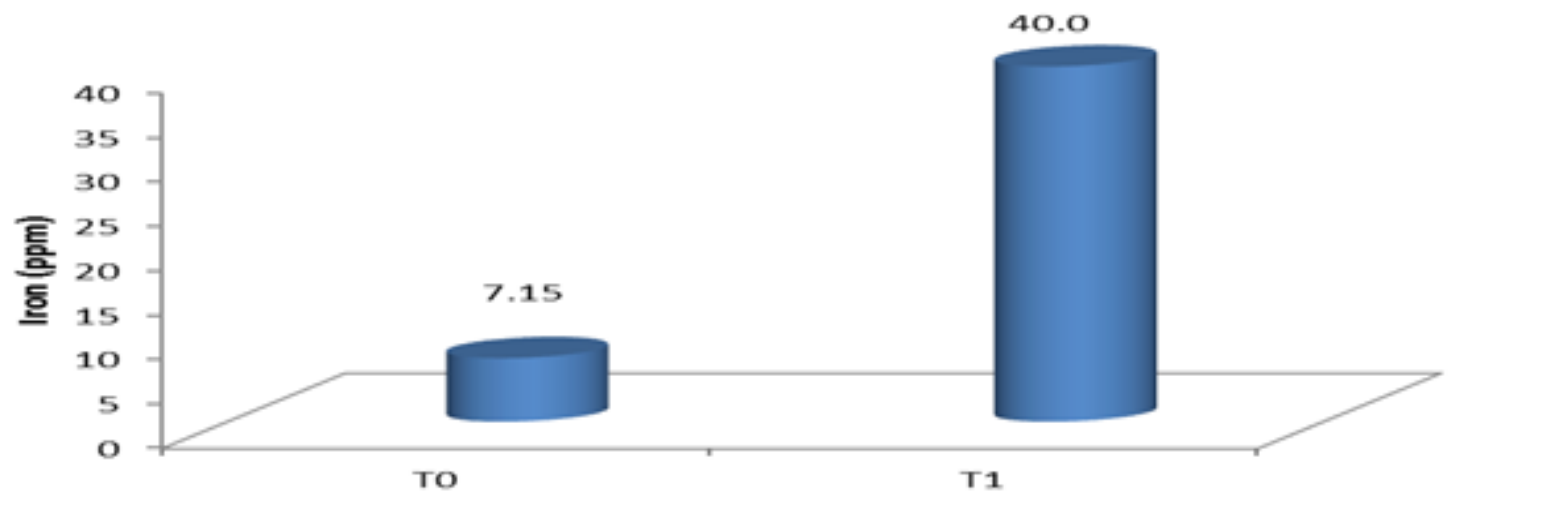

Figure 8. Iron content (ppm) mean values in ready to drink beverage

\section{Microbiological analysis}

The total plate count average mean values at $1^{\text {st }}$ day of storage for $T_{0}$ and $T_{1}$ was 2.17 $\log _{10} \mathrm{cfu} / \mathrm{mL}$ and after 90 days of storage, the TPC mean value for $\mathrm{T}_{0}$ and $\mathrm{T}_{1}$ was 2.34 $\log _{10} \mathrm{cfu} / \mathrm{mL}$. The TPC was more in case of $\mathrm{T}_{0}\left(2.28 \log _{10} \mathrm{cfu} / \mathrm{mL}\right)$ while TPC was less in $\mathrm{T}_{1}\left(2.22 \log _{10} \mathrm{cfu} / \mathrm{mL}\right)$. The change in TPC of beverage might be due to untreated fruit pulp used for making ready to drink beverage. Pulp may be contaminated with bacteria, yeast and mold. The data depicts the minimum increase in microbial load after storage interval which might be due to initial load and untreated fruit pulp. However, during storage all treatments were found acceptable (Table 2).

Table 2. Mean value for TPC $\left(\log _{10} \mathrm{cfu} / \mathrm{mL}\right)$ of ready to drink beverage during storage

\begin{tabular}{|c|c|c|c|c|c|}
\hline \multirow{2}{*}{ Treatment } & \multicolumn{4}{|c|}{ Storage (Days) } & \multirow{2}{*}{ Mean } \\
\hline & $\mathbf{0}$ & 30 & 60 & 90 & \\
\hline $\mathrm{T}_{0}$ & 2.20 & 2.25 & 2.29 & 2.39 & 2.28 \\
\hline $\mathrm{T}_{1}$ & 2.15 & 2.21 & 2.23 & 2.31 & 2.22 \\
\hline Mean & 2.17 & 2.23 & 2.26 & 2.34 & \\
\hline
\end{tabular}

The mold count was more in case of $\mathrm{T}_{0}$ (1.87 $\log _{10} \mathrm{cfu} / \mathrm{mL}$ ) while less mold count was found in $\mathrm{T}_{1}\left(1.75 \log _{10} \mathrm{cfu} / \mathrm{mL}\right)$. The change in $\mathrm{MC}$ of beverage might be due to untreated fruit pulp used for making ready to drink beverage (Table 3). Pulp may be contaminated with yeast and mold. The data depicts the minimum increase in microbial load after storage interval which might be due to initial load and untreated fruit pulp. However, during storage all treatments were found acceptable.

Table 3. Mean values for mold count $\left(\log _{10} \mathrm{cfu} / \mathrm{mL}\right)$ of ready to drink beverage in the storage period

\begin{tabular}{|c|c|c|c|c|c|}
\hline \multirow{2}{*}{ Treatment } & \multicolumn{4}{|c|}{ Storage (Days) } & \multirow{2}{*}{ Mean } \\
\hline & $\mathbf{0}$ & 30 & 60 & 90 & \\
\hline $\mathrm{T}_{0}$ & 1.76 & 1.84 & 1.92 & 1.97 & 1.87 \\
\hline $\mathrm{T}_{1}$ & 1.61 & 1.71 & 1.80 & 1.87 & 1.75 \\
\hline Mean & 1.68 & 1.78 & 1.86 & 1.92 & \\
\hline
\end{tabular}




\section{Sensory analysis}

Color's high score was obtained by the judges in case of $\mathrm{T}_{0}$ (7.30) whereas color's less score was obtained in case of $\mathrm{T}_{1}$ (6.96). Different coloring pigments of the fruit and addition of $\mathrm{FeSO}_{4} .7 \mathrm{H}_{2} \mathrm{O}$ in beverage, causes the change in color of RTS beverage. However, the color score achieved for both treatments was acceptable. The high flavor score was achieved in case of $\mathrm{T}_{0}(7.40)$ whereas less flavor score was obtained for $\mathrm{T}_{1}$ (6.70). Beverage flavor may be changed because of the addition of $\mathrm{FeSO}_{4}$. Beverage flavor is improved by the $\mathrm{pH}$. However, acceptable score of flavor was achieved from both treatments. The score of taste was more for $\mathrm{T}_{0}(7.46)$ whereas the minimum score for taste was obtained for $\mathrm{T}_{1}(6.46)$.
Taste of drink was changed may be due to the addition of $\mathrm{FeSO}_{4}$ as well as change in acidity of ready to drink beverage. However, acceptable score for taste was achieved for both treatments. The mouth feel score exceed in case of $\mathrm{T}_{0}$ (7.36) as compared to $\mathrm{T}_{1}$ (6.53). The change in mouth feel of ready to drink beverage might be due to addition of $\mathrm{FeSO}_{4} .7 \mathrm{H}_{2} \mathrm{O}$ and change in acidity. In case of $\mathrm{T}_{0}$, the high score of overall acceptability was given by judges (7.66) whereas less score of overall acceptability was observed for $\mathrm{T}_{1}$ (6.86). The variation in overall acceptability of ready to drink beverage may be because of the decrease in color and flavor. However acceptable score was achieved for both treatments for overall acceptability (Figure 9).

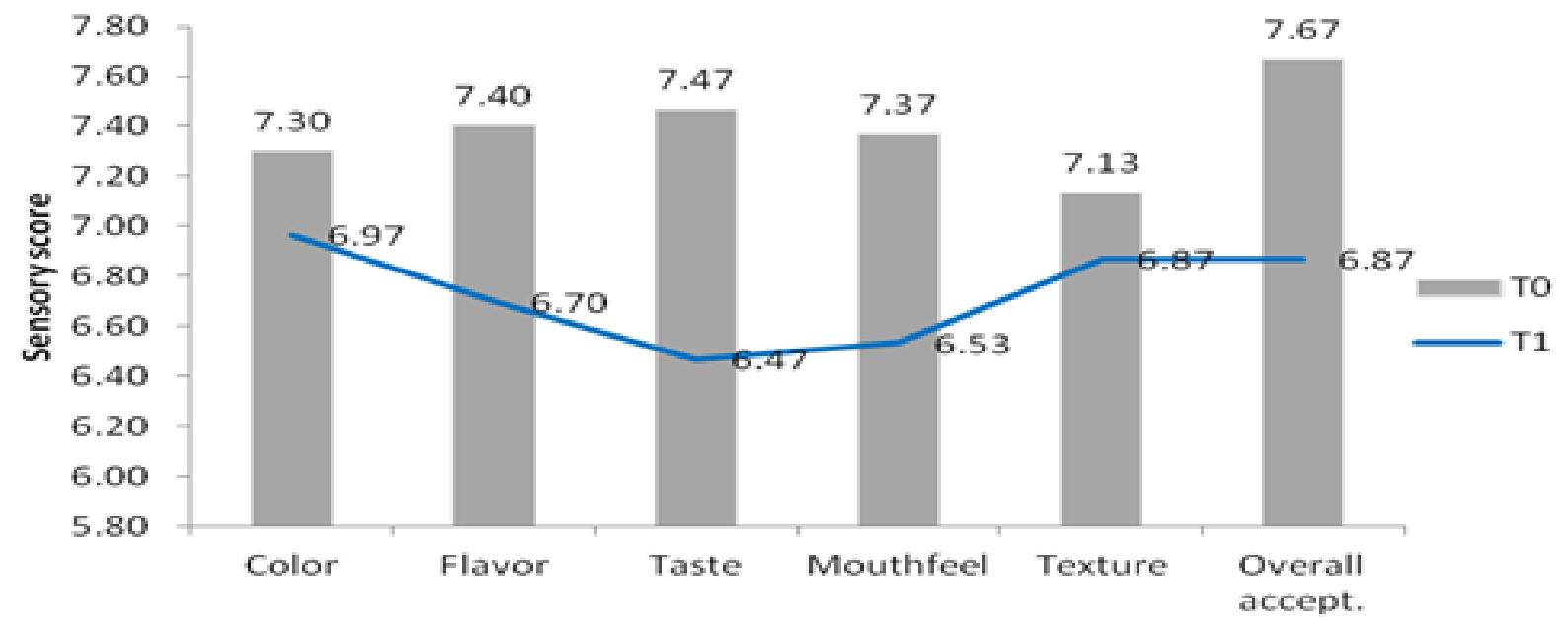

Figure 9. Sensory score mean values for ready to drink beverage

\section{Efficacy study of iron fortified drink}

In the present scenario, food based approach has emerged as a suitable technology to combat micronutrient disorders [20]. In order to combat with the existing situation of iron deficiency anemia in Pakistan, fortification of food is the best strategy [21] and for this purpose food fortified with iron must be stable [22, 23] safe, acceptable and consumable by the targeted subjects [24]. The effect of an iron fortification can only be judged through efficacy studies with improvement in the iron status of the target subjects. Hemoglobin $(\mathrm{Hb})$ level is the key factor for the efficacy study. To determine the degree of anemia, important parameter is Hb level [25].

A preliminary demographic survey of 100 female students was conducted. During this survey, $\mathrm{Hb}$ level in blood of 50 females student was checked at University Medical and Diagnostic Center, University of Sargodha, Sargodha. Out of 50, forty volunteer students (19-22 Y), who were 
anemic $(\mathrm{Hb}<12 \mathrm{~g} / \mathrm{dL})$ were enrolled for the efficacy study (Table 4). One group received ready to drink beverage without fortification, while the other group received fortified drink containing 40 ppm $\mathrm{FeSO}_{4} .7 \mathrm{H}_{2} \mathrm{O}$ for a period of 3 months. A few of the subjects have hemoglobin level $(\mathrm{Hb})<8 \mathrm{~g} / \mathrm{dL}$ while more fell in the group between $\mathrm{Hb}$ level of $8-9 \mathrm{~g} / \mathrm{dL}$ (Table 5). After 3 months, the overall increase in level of $\mathrm{Hb}$ was from 9.85 to $9.98 \mathrm{~g} / \mathrm{dL}$ in case of drink without fortification while it was 10.53 to $11.52 \mathrm{~g} / \mathrm{dL}$ after 3 months in case of drink with fortification. Highly significant $(p \leq 0.01)$ variance was achieved in case of treatments and storage also has significant ( $p>0.05)$ effect. The increase in $\mathrm{Hb}$ in case of $\mathrm{FeSO}_{4} .7 \mathrm{H}_{2} \mathrm{O}$ fortified drink was of 0.094 $\mathrm{g} / \mathrm{dL}$ while in non-fortified drink was 0.0132 $\mathrm{g} / \mathrm{dL}$. $9.40 \%$ and $1.32 \%$ reduction in iron deficiency was observed in these trials $\left.\begin{array}{llll}\text { (Table } & 6 & \& & 7\end{array}\right)$.

Table 4. Mean values for Hemoglobin level in females during 90 days

\begin{tabular}{|c|c|c|c|}
\hline \multirow{2}{*}{ Treatment } & \multicolumn{2}{|c|}{ Days } & \multirow{2}{*}{ Mean } \\
\cline { 2 - 4 } & 1 & 90 & $9.915 \mathrm{~b}$ \\
\hline T0 & 9.85 & 9.98 & $11.025 \mathrm{a}$ \\
\hline T1 & 10.53 & 11.52 & \\
\hline Mean & $10.19 \mathrm{a}$ & $10.75 \mathrm{~b}$ & \\
\hline
\end{tabular}

Table 5. Initial hemoglobin level in females

\begin{tabular}{|c|c|c|c|}
\hline \multirow{2}{*}{ Age groups (years) } & \multicolumn{3}{|c|}{ Hemoglobin (Hb) level (mg/dL) } \\
\cline { 2 - 4 } & $<8$ & $8-12$ & $>12$ \\
\hline $16-25(\mathrm{n}=40)$ & 0 & 55 & 24 \\
\hline
\end{tabular}

Table 6. Hemoglobin level of females before and after taking drink without fortification

\begin{tabular}{|c|c|c|}
\hline \multirow{2}{*}{ Variables } & \multicolumn{2}{|c|}{ Control Treatment } \\
\cline { 2 - 3 } & $\begin{array}{c}\text { Initial Hb level before studies } \\
\text { Mean } \mathbf{\pm} \text { SD } \\
(\mathbf{n}, \mathbf{\%})\end{array}$ & $\begin{array}{c}\text { Final Hb level after studies } \\
\text { Mean } \mathbf{\pm} \text { SD } \\
(\mathbf{n}, \mathbf{\%})\end{array}$ \\
\hline Haemoglobin $(\mathrm{g} / \mathrm{dL})$ & $9.85 \pm 1.27$ & $9.98 \pm 1.13$ \\
& $(20,100 \%)$ & $9.69 \pm 1.05$ \\
& $9.48 \pm 1.12$ & $(16,80 \%)$ \\
\hline Iron Deficient & $(16,80 \%)$ & $11.15 \pm 0.50$ \\
$($ Hb is less than $11 \mathrm{~g} / \mathrm{dL})$ & $11.33 \pm 0.47$ & $(4,20 \%)$ \\
\hline Non-Iron Deficient & $(4,20 \%)$ & \\
\hline
\end{tabular}

Table 7. Hemoglobin level of females before and after taking drink with fortification

\begin{tabular}{|c|c|c|}
\hline \multirow{2}{*}{ Variables } & \multicolumn{2}{|c|}{ Experimental Treatment } \\
\cline { 2 - 3 } & $\begin{array}{c}\text { Initial Hb level before studies } \\
\text { Mean } \mathbf{\pm} \text { SD } \\
(\mathbf{n}, \boldsymbol{\%})\end{array}$ & $\begin{array}{c}\text { Final Hb level after studies } \\
\text { Mean } \pm \text { SD } \\
(\mathbf{n}, \mathbf{\%})\end{array}$ \\
\hline Hemoglobin $(\mathrm{g} / \mathrm{dL})$ & $9.97 \pm 1.35$ & $10.50 \pm 1.06$ \\
$(20,100 \%)$ & $(20,100 \%)$ \\
\hline Iron Deficient & $9.53 \pm 1.12$ & $10.89 \pm 1.10$ \\
$(\mathrm{Hb}$ is less than $11 \mathrm{~g} / \mathrm{dL})$ & $(10,50 \%)$ & $(10,50 \%)$ \\
\hline Non-Iron Deficient & $11.53 \pm 0.45$ & $12.15 \pm 0.54$ \\
$(\mathrm{Hb}$ is greater than $11 \mathrm{~g} / \mathrm{dL})$ & $(10,50 \%)$ & $(10,50 \%)$ \\
\hline
\end{tabular}




\section{Conclusion}

From the above results / discussion, it is concluded that seasonal fruit are suitable as a source of iron for anemic patients. The ready to drink beverage is good vehicle for iron fortification and also a source of utilization of seasonal fruits. Food fortification is a practical approach to reach at the risk segments of the population at minimal cost. So, the iron deficiency anemia can be controlled with the help of consumption of fortified beverages that are very common in our society. It is helpful to increase the nutrient intake of children and their nutritional status. Beverages can be consumed without further processing/cooking, so it is termed as vehicle for fortification which is also easy to administer. To overcome the situation of iron deficiency anemia in Pakistan, a nutritious fruit and vegetables based beverage was prepared. The consumption of iron-fortified ready to drink beverage, using $\mathrm{FeSO}_{4}$ as fortificant can effectively improve iron status, thereby, reducing iron deficiency.

\section{Authors' contributions}

Conceived and designed the experiments: $\mathrm{M}$ Nadeem, A Mahmood \& ZI Khan, Performed the experiments: A Shaukat \& L Rukh, Analyzed the data: MN Riaz, Contributed reagents/ materials/ analysis tools: MA Murtaza, A Din, H Fatima \& GM Din, Wrote the paper: A Shaukat, M Nadeem \& A Mahmood.

\section{References}

1. WHO (2008). Worldwide Prevalence of Anemia 1993-2005 WHO Global Database on Anemia. Williams DM, Lynch RE, Cartwright GE. Prognostic factors in Aplastic anaemia. Clin Haematol 7: 467-74.

2. WHO (2001). Iron deficiency anaemia, assessment, prevention and control: a guide for programme managers. Switzerland: Geneva.
3. Johnson-Wimbley TD \& Graham DY (2011). Diagnosis and management of iron deficiency anemia in the 21st century. Therap. Adv. Gastroenterol 4: 177-184.

4. Silverberg DS, Wexler D \& Sheps D (2001) The effect of correction of

5. Saeed A, Anwar A, Asif A, Zulfiqar, A, Muhammad R \& Tariq I (2013). Iron status of the Pakistani populationcurrent issues and strategies. Asia. Pac J Clin Nutr 22: 340-347.

6. Zlotkin SH, Christofides AL, Hyder SM, Schauer CS, Tondeur MC and Sharieff W (2004). Controlling ID A through the use of home-fortified complementary foods. Ind $\mathrm{J}$ Ped 71: 1015-9.

7. Shruti P \& Vasudeva S (2013). Food Fortification to Combat Iron Deficiency Anaemia. Intr J Ad Nut. hlth Sci 1: 39:47-62.

8. Arts IC \& Hollman PC (2005). Polyphenols and disease risk in epidemiologic studies. Am J Clin Nutr 81: 317-325.

9. Mink PJ, Scrafford CG, Barraj L M, Harnack L, Hong CP, Nettleton J A, Jacobs DR \& Jr (2007). Flavonoid intake and cardiovascular disease mortality: A prospective study in postmenopausal women. Am J Clin Nutr 85: 895-909.

10. Yang Z, Ma Y, Chen L, Xie R, Zhang X. \& Zhang B (2011). Differential transcript abundance and genotypic variation of four putative allergenencoding gene families in melting peach. Tree Genet Genomes 7: 903-916.

11. Manzoor M, Anwar F, Saari N \& Ashraf M (2012). Variations of antioxidant characteristics and mineral contents in pulp and peel of different Apple (Malus domestica Borkh.) cultivars from Pakistan. Molecules 17: 390-407. 
12. Pramer C \& Kaushal MK (1982). Wild fruits of Sub-Himayalyan Region Kalyani Publishers, New Delhi, India.

13. Wootton-Beard PC, Moran A \& Ryan L (2011). Stability of the antioxidant capacity and total polyphenol content of 23 commercially available vegetable juices before and after in vitro digestion as measured by FRAP, DPPH, ABTS and Folin Ciocalteu methods. Food Res Intr 44: 217-224.

14. Pitalua E, Jimenez M, Vernon-Carter EJ \& Beristain CI (2010). Antioxidative activity of microcapsules with beetroot juice using gum Arabic as wall material. Food Bio Prod Pro 88: 253-258.

15. AOAC (2000). Official methods of analysis. Association of Official Analytical Chemists International (17th ed.) Arlington, VA, USA.

16. Balaswamy K, Pamidighantam PR, Allani N \& Akula S (2011). Preparation of Sour Grape (VitisVinifera) Beverages and Evaluation of their Storage Stability. J Food Pro Tech 1: 23.

17. AACC (2000). Approved Methods of the American Association of Cereal Chemist. 10th Ed. St. Paul, MN, USA.

18. Duhan AN, Khetarpaul \& Bishnoi S (2002). Changes in phytates and $\mathrm{HCl}$ extractability of calcium, phosphorus and iron of soaked, dehulled, cooked and sprouted pigeon pea cultivar (UPAS-120). Plant Foods Hum. Nutr 57: 275-284.

19. Steel RGD, Torrie JH \& Dickey DA (1997). Principles and procedures of
statistics.A biometrical approach. Singapore: (3rd Ed.). McGraw Hill Book Co. Inc., NY, USA. 400-428.

20. Rehman, S, Anjum SA \& Anjum FM (2006). Effect of storage on the stability of Iron (Ferrous) fortified whole wheat flour used for the production of Naan. $J$ Food Proc Press 30: 323-324.

21. Samuelson G, Lonnerdal B \& Kempe B (2000). A follow-up study of serum ferritin and transferrin receptor concentrations in Swedish adolescents at age 17 to age 15. Acta Paediatr 89: 1162-1168.

22. Rehman, S, Anjum SA \& Anjum FM (2003). Chemical, rheological and storage studies of iron fortified whole wheat flour. Pak J Food Sci 13: 73-76.

23. Benjamin ACB \& Guinard JX (2003). Novel approaches and application of contemporary sensory evaluation practices in iron fortification programs. Crit Rev Food Sci Nutr 43: 379-400.

24. Hurrell RF (1979). Genealogies in the Library of Congress: A Bibliography.

25. Cook JD, Skikne BS \& Baynes RD (1996). Serum ferritin receptors for the assessment of iron status. In: Halberg NG. Asp (Eds.) Nutr Hlth Dis 49-58.

26. Bajwa EE, Naeem Z, Anjum J \& Nazir (2003). Development, standardization and storage studies on watermelonlemon juice. Pak J Food Sci 12: 21-24.

27. Nilugin $S$ \& Mahendran $T$ (2011). Preparation of ready-to-serve (RTS) beverage from palmyrah (Borassus flabellifer L.) fruit pulp. J Agri Sci 5(2): 80-88. 